\title{
The Impact of Global Crisis on the Innovative Processes in Sustainable Development of Russia as a Resource-Mining Country
}

\author{
Olesia Miliushenko ${ }^{1}$, Aleksander Kovalev ${ }^{1}$, and Margarita Zhidkova ${ }^{2, *}$ \\ ${ }^{1}$ Financial University under the Government of the Russian Federation, Omsk Branch, 644099 \\ Partizanskaya st. 6, Omsk, Russia \\ ${ }^{2}$ Moscow Automobile and Road Construction State Technical University (MADI), 125319 \\ Leningradsky prospect 64, Moscow, Russia
}

\begin{abstract}
The global crisis processes that began in 2008 are special, as they signify a change in the epoch shift - from industrial to post-industrial, with a radical reduction in the negative impact on nature and a careful attitude to non-renewable natural resources. The innovations arising during this period affect all spheres of sustainable development - from environmental and technological to economic and social ones. The penetration of global crisis processes into Russian economy has reduced the demand for innovative products, has reoriented investments to maintain output volumes instead of improving the environmental performance of production. The negative consequences of the crisis in Russia include reducing the chances of survival for emerging innovative enterprises, reducing the share of regions that have taken the path of sustainable development, when industrial output growth does not worsen the ecological situation. Therefore, the relevance of an accurate analysis of the factors influencing the global crisis on the innovative development of industry, defining prospects for reducing resource use and investing in environmental protection measures, is greater than ever. In this article, a factor analysis of the impact of the crisis on the innovation activities of Russian industrial firms in the crisis years of 2008 and 2015 was carried out based on data on the main indicators of the enterprises activities. The authors highlighted a number of independent factors influencing crises on sustainable development, with special attention paid to innovative human potential.
\end{abstract}

\section{Introduction}

In 1987, a specially created UN World Commission on Environment and Development formulated the Concept of Sustainable Development, the idea of which was that economic development should not be detrimental to the environment. Subsequently, the concept was approved by the world community (UN Conference on Environment and Development in Rio de Janeiro in 1992) and was taken into account when developing and implementing

\footnotetext{
${ }^{*}$ Corresponding author: info@,madi.ru
} 
international and national economic policies. At the present time, ecology has gradually begun to come to the fore in the system of global relations, becoming the engine of sustainable development.

Currently, a new model of development of the world economy is being formed. The catalyst for this process was the financial and economic crisis. Ecology is increasingly becoming the engine of economic development, largely affecting the political, social and cultural spheres. This is manifested in the formation of international and national sustainable development policies, special amendments to the laws, large-scale investment and introduction of innovations in environmental projects. Russia needs to quickly take into account these trends, reorienting the development of the economy on environmental way. Crisis-related obstacles to sustainable development are particularly relevant for resourceproducing countries, such as Russia. The impact of the crisis on sustainable development occurs in the form of reducing investment in environmental protection and technological innovation, underinvestment of human development, aging of fixed capital and maintaining a high level of resource consumption.

\section{Materials and Methods}

At present, environmental situation in Russian economy remains extremely serious, aggravated by the crisis processes in the national and world economy. Statistics show that Russia occupies one of the last places in the world in many areas of environmental protection. Russia ranks first in the world in terms of pollutant emissions per unit of GDP. Russia is in third place in the world in terms of greenhouse gas emissions, and in terms of radioactive contamination it is in 1 st place. There are serious problems in the field of recycling and many other areas [1-4].

The reasons and consequences of the influence of global crisis phenomena in the economy on the transition to sustainable development and the phased solution of environmental problems are of particular interest from the point of view of planning and forecasting economic activity [5-8]. We analyzed the impact of the crises of 2008 and 2015 on the innovation activities of Russian enterprises. All data was obtained from the first independent rating agency FIRA [9]. The following variables were used for the analysis: "Average number of all employees in research and development", "Total salaries for all employees in research and development", "Investments in machinery, equipment, vehicles".

\section{Results and Discussion}

Factor analysis was conducted for 2008 and 2015. We start the review from 2015, where the analysis was carried out on the basis of the variables presented above and it is the following (Tab. 1).

Table 1. Correlation matrix of factor analysis for 2015 .

\begin{tabular}{|c|c|c|c|c|c|c|c|}
\hline Indicators & $\begin{array}{c}\text { Av. num. } \\
\text { of all } \\
\text { emp. in } \\
\text { R\&D }\end{array}$ & $\begin{array}{c}\text { Tot. sal. } \\
\text { for all } \\
\text { empl. in } \\
\text { R\&D }\end{array}$ & $\begin{array}{c}\text { Av. num. } \\
\text { of emp. in } \\
\text { Technic. } \\
\text { R\&D }\end{array}$ & $\begin{array}{c}\text { Tot. sal. } \\
\text { in } \\
\text { Technic. } \\
\text { R\&D }\end{array}$ & $\begin{array}{c}\text { Dom. } \\
\text { goods } \\
\text { shipped } \\
\text { in R\&D }\end{array}$ & $\begin{array}{c}\text { Shipped } \\
\text { own- } \\
\text { prod. } \\
\text { goods to } \\
\text { R\&D }\end{array}$ & $\begin{array}{c}\text { Inves. in } \\
\text { machinery, } \\
\text { equipment, } \\
\text { vehicles }\end{array}$ \\
\hline $\begin{array}{c}\text { Av. num. of all } \\
\text { emp. in R\&D }\end{array}$ & 1.000 & 0.948 & 0.674 & 0.412 & 0.487 & 0.639 & 0.719 \\
\hline $\begin{array}{c}\text { Tot. sal. for all } \\
\text { empl. in R\&D }\end{array}$ & 0.948 & 1.000 & 0.683 & 0.369 & 0.478 & 0.655 & 0.746 \\
\hline
\end{tabular}




\begin{tabular}{|c|c|c|c|c|c|c|c|}
\hline $\begin{array}{c}\text { Av. num. of emp. } \\
\text { in Technic. R\&D }\end{array}$ & 0.674 & 0.683 & 1.000 & 0.884 & 0.861 & 0.976 & 0.900 \\
\hline $\begin{array}{c}\text { Tot. sal. in } \\
\text { Technic. R\&D }\end{array}$ & 0.412 & 0.369 & 0.884 & 1.000 & 0.922 & 0.909 & 0.666 \\
\hline $\begin{array}{c}\text { Dom. goods } \\
\text { shipped in R\&D }\end{array}$ & 0.487 & 0.478 & 0.861 & 0.922 & 1.000 & 0.866 & 0.740 \\
\hline $\begin{array}{c}\text { Shipped own- } \\
\text { prod. goods to } \\
\text { R\&D }\end{array}$ & 0.639 & 0.655 & 0.976 & 0.909 & 0.866 & 1.000 & 0.809 \\
\hline $\begin{array}{c}\text { Investments in } \\
\text { machinery, } \\
\text { equipment, } \\
\text { vehicles }\end{array}$ & 0.719 & 0.746 & 0.900 & 0.666 & 0.740 & 0.809 & 1.000 \\
\hline
\end{tabular}

The indicator "Total salaries in Technical Research and Development" closely correlates with the following indicators: "Domestic goods shipped in research and development", "Shipped own-produced goods to research and development", as well as "Investments in machinery, equipment, vehicles." The variable "Total salaries in Technical Research and Development" is associated only with the variable "Shipped own-produced goods to research and development."

So, having considered the correlation matrix, we can conclude that the original features are combined into four groups:

The first group consists of 2 variables: "Average number of all employees in research and development", "Payroll fund for all employees in research and development".

The second group consists of 2 variables: "Total salaries in technical research and development", "Average number of all employees in Technical Research and Development.

The third group consists of variables: "Domestic goods shipped in research and development", "Shipped own-produced goods to research and development".

The variable "Investments in machinery, equipment, vehicles" forms the fourth group.

There are 4 hidden factors that are sufficient to explain the underlying features. Next, we proceed to the determination of the optimal number of factors, or consider the fraction of the total variance explained. Tab. 2 shows the number of major components.

Table 2. Explained cumulative variance for 2015.

\begin{tabular}{|c|c|c|c|c|c|c|}
\hline \multirow{2}{*}{ Comp. } & \multicolumn{3}{|c|}{ Starting own values } & \multicolumn{3}{c|}{$\begin{array}{c}\text { The sum of the squares of } \\
\text { the load extraction }\end{array}$} \\
\cline { 2 - 7 } & Total & \% disp. & Sum. \% & Total & $\%$ disp. & Sum. \% \\
\hline 1 & 6.426 & 91.797 & 91.797 & 6.426 & 91.797 & 91.797 \\
\hline 2 & 0.305 & 4.350 & 96.147 & - & - & - \\
\hline 3 & 0.117 & 1.678 & 97.825 & - & - & - \\
\hline 4 & 0.104 & 1.487 & 99.311 & - & - & - \\
\hline 5 & 0.036 & 0.515 & 99.826 & - & - & - \\
\hline 6 & 0.010 & 0.143 & 99.969 & - & - & - \\
\hline 7 & 0.002 & 0.031 & 100.000 & - & - & - \\
\hline
\end{tabular}

Consider factors whose own values are more than 1. As you can see, only one factor satisfies a given value. This factor is $91.797 \%$ of the total dispersion, which is more than $80 \%$. Consequently, the optimal number of factors is equal to 1 . Since the gap at the level of the second factor is weakly expressed, it is recommended to use the first factor. That is, the "Rolling stones chart" illustrates the previously made conclusions about the number of 
necessary factors. Due to the fact that only one component fits, it is impossible to rotate the solution, therefore, it is impossible to build an inverse matrix. Consider the graph of normalized simple stress, i.e. the Rolling stones chart (Fig. 1).

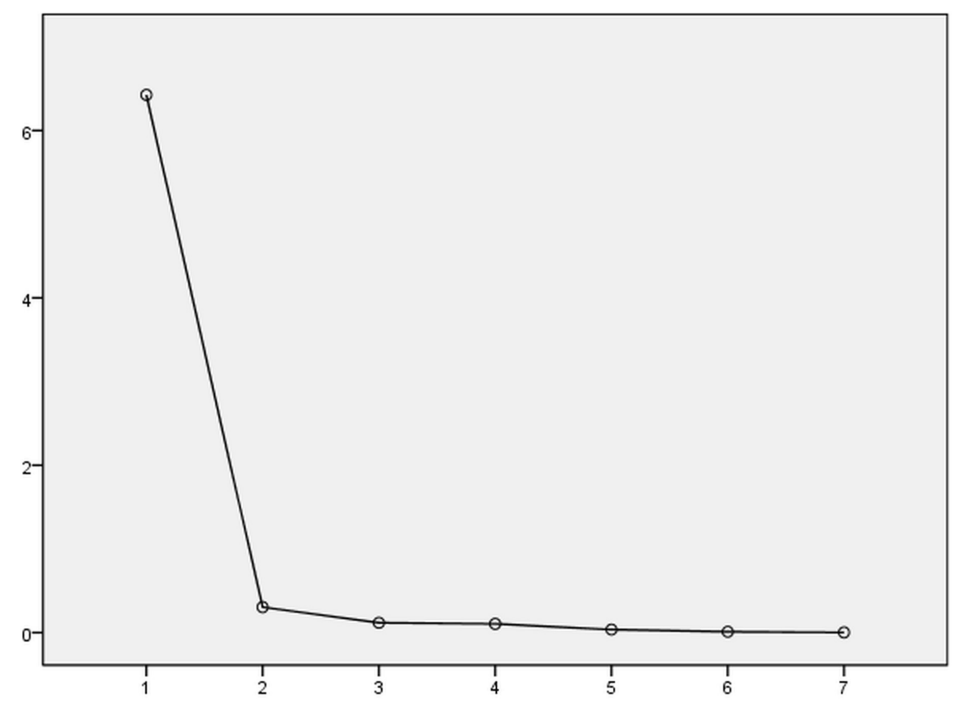

Fig. 1. Rolling stones chart of own values depending on the number of a component (2015).

Thus, factor analysis can be considered as an acceptable method for analyzing the situation under study. Next, we turn to the 2008 crisis year. The correlation matrix of factor analysis for 2008 is shown in Tab. 3.

Table 3. Correlation matrix of factor analysis for 2008 .

\begin{tabular}{|c|c|c|c|c|c|c|c|}
\hline Indicators & $\begin{array}{c}\text { Av. num. } \\
\text { of all } \\
\text { emp. in } \\
\text { R\&D }\end{array}$ & $\begin{array}{c}\text { Tot. sal. } \\
\text { for all } \\
\text { empl. in } \\
\text { R\&D }\end{array}$ & $\begin{array}{c}\text { Av. num. } \\
\text { of emp. in } \\
\text { Technic. } \\
\text { R\&D }\end{array}$ & $\begin{array}{c}\text { Tot. sal. } \\
\text { in } \\
\text { Technic. } \\
\text { R\&D }\end{array}$ & $\begin{array}{c}\text { Dom. } \\
\text { goods } \\
\text { shipped } \\
\text { in R\&D }\end{array}$ & $\begin{array}{c}\text { Shipped } \\
\text { own- } \\
\text { prod. } \\
\text { goods to } \\
\text { R\&D }\end{array}$ & $\begin{array}{c}\text { Inves. in } \\
\text { machinery, } \\
\text { equipment, } \\
\text { vehicles }\end{array}$ \\
\hline $\begin{array}{c}\text { Av. num. of all } \\
\text { emp. in R\&D }\end{array}$ & 1.000 & 0.948 & 0.674 & 0.412 & 0.487 & 0.639 & 0.719 \\
\hline $\begin{array}{c}\text { Tot. sal. for all } \\
\text { empl. in R\&D }\end{array}$ & 0.948 & 1.000 & 0.683 & 0.369 & 0.478 & 0.655 & 0.746 \\
\hline $\begin{array}{c}\text { Av. num. of emp. } \\
\text { in Technic. R\&D }\end{array}$ & 0.674 & 0.683 & 1.000 & 0.884 & 0.861 & 0.976 & 0.900 \\
\hline $\begin{array}{c}\text { Tot. sal. in } \\
\text { Technic. R\&D }\end{array}$ & 0.412 & 0.369 & 0.884 & 1.000 & 0.922 & 0.909 & 0.666 \\
\hline $\begin{array}{c}\text { Dom. goods } \\
\text { shipped in R\&D }\end{array}$ & 0.487 & 0.478 & 0.861 & 0.922 & 1.000 & 0.866 & 0.740 \\
\hline $\begin{array}{c}\text { Shipped own- } \\
\text { prod. goods to } \\
\text { R\&D }\end{array}$ & 0.639 & 0.655 & 0.976 & 0.909 & 0.866 & 1.000 & 0.809 \\
\hline $\begin{array}{c}\text { Investments in } \\
\text { machinery, } \\
\text { equipment, } \\
\text { vehicles }\end{array}$ & 0.719 & 0.746 & 0.900 & 0.666 & 0.740 & 0.809 & 1.000 \\
\hline
\end{tabular}


After the KMO and Bartlett tests, it is clear that the results of this test vary from 0 (the factor model is absolutely inapplicable) to 1 (the factor model perfectly describes the data structure). Factor analysis should be considered suitable if $\mathrm{KMO}$ is in the range from 0.5 to 1. In this case, this indicator is equal to 0.696 (approximately 69.6\%), which is an acceptable result.

The first group included: "The average number of employees in research and developments," "Total salaries of all employees in tests and developments."

The second group included: "The Average number of all employees in Technical Research and Development", "Shipped own-produced goods to research and development, "Total salaries in Technical Research and Development ".

It can be noted that 2 hidden factors are enough to explain the original features. The cumulative variance explained for 2008 is presented in Table 4. As can be observed, the first 2 factors matter more than 1 . Together, these factors account for $93.638 \%$ of the total variance, therefore, the optimal number of factors is 2 .

Table 4. Explained cumulative variance for 2008 .

\begin{tabular}{|c|c|c|c|c|c|c|}
\hline \multirow{2}{*}{ Comp. } & \multicolumn{3}{|c|}{ Starting own values } & \multicolumn{3}{c|}{$\begin{array}{c}\text { The sum of the squares of } \\
\text { the load extraction }\end{array}$} \\
\cline { 2 - 7 } & Total & \% disp. & Sum. \% & Total & \% disp. & Sum. \% \\
\hline 1 & 5.418 & 77.393 & 77.393 & 5.418 & 77.393 & 77.393 \\
\hline 2 & 1.137 & 16.245 & 93.638 & 1.137 & 16.245 & 93.638 \\
\hline 3 & 0.225 & 3.211 & 96.849 & - & - & - \\
\hline 4 & 0.139 & 1.991 & 98.840 & - & - & - \\
\hline 5 & 0.064 & 0.912 & 99.752 & - & - & - \\
\hline 6 & 0.012 & 0.173 & 99.925 & - & - & - \\
\hline 7 & 0.005 & 0.075 & 100.000 & - & - & - \\
\hline
\end{tabular}

Next, consider the graph of normalized simple stress, i.e. the Rolling stones chart (Fig. 2).

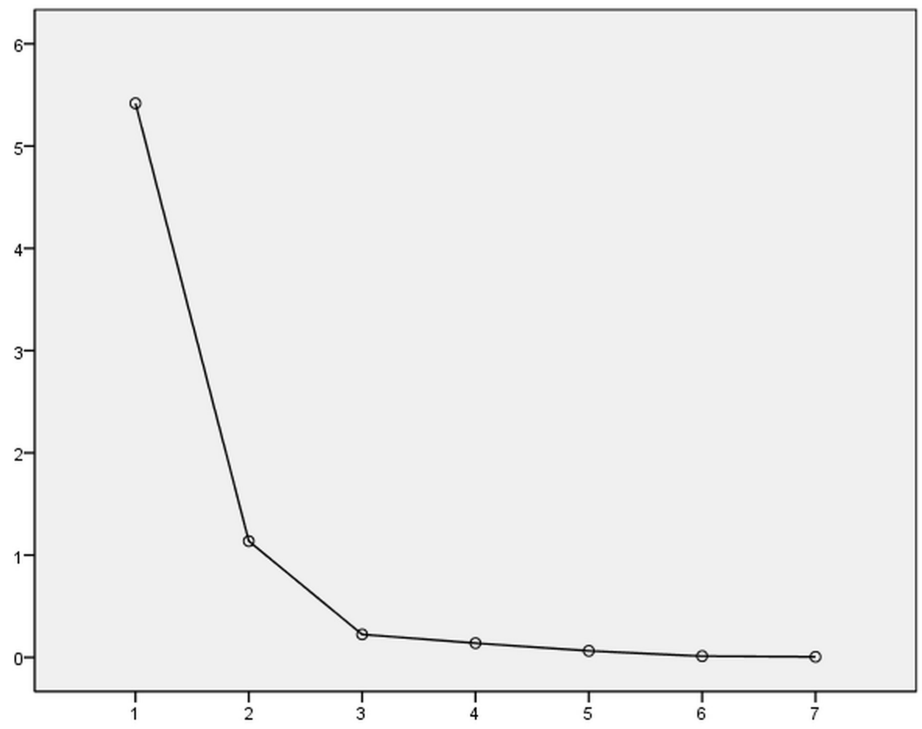

Fig. 2. Rolling stones chart of own values depending on the number of a component (2008). 
The third group includes the indicators: "Shipped own-produced goods to research and development", "Domestic goods shipped in research and development", "Total salaries in technical tests and developments".

The fourth group includes "Domestic goods shipped in research and development", "Investments in machinery, equipment, vehicles".

The fifth group includes the indicator "Total salaries of all employees in research and development".

The graph ("Rolling stones") shows the dependence of the own values of the factors on their numbers in the order of selection. As you can see, the gap occurs at the second level, that tells us that the number of necessary factors is 2 .

From the analysis of table 5 we can conclude that the first factor has high positive coefficients with the following variables: " Total salaries in Technical Research and Development ", "Shipped goods of own production in research and development", " Shipped own-produced goods to research and development ", " Average number of all employees in research and development."

Consequently, with the growth of this factor, the index of the indicators listed above increases. Based on this, we should give the name of the factor "Index of current assets utilization."

Table 5. Rotated Component Matrix for 2008.

\begin{tabular}{|c|c|c|}
\hline \multirow{2}{*}{ Indicators } & \multicolumn{2}{|c|}{ Component } \\
\cline { 2 - 3 } & $\mathbf{1}$ & $\mathbf{2}$ \\
\hline Average number of all employees in research and development & 0.257 & 0.937 \\
\hline Total salaries for all employees in research and development & 0.244 & 0.955 \\
\hline Average number of all employees in Technical Research and \\
Development & 0.844 & 0.509 \\
\hline Total salaries in Technical Research and Development & 0.974 & 0.137 \\
\hline Domestic goods shipped in research and development & 0.921 & 0.249 \\
\hline Shipped own-produced goods to research and development & 0.863 & 0.452 \\
\hline Investments in machinery, equipment, vehicles & 0.644 & 0.652 \\
\hline
\end{tabular}

The second factor has high positive coefficients with the variables "Average number of all employees in Technical Research and Development", "Total salaries for all employees in research and development", "Investments in machinery, equipment, vehicles". We can also note that with the growth of this factor, the share of these indicators increases. So, this factor should be given the name "Index of economic development of enterprises engaged in innovative activity."

\section{Conclusion}

After a factor analysis of the impact of the crisis on the innovation activities of enterprises in Russian Federation in the crisis years of 2008 and 2015, the following can be concluded. Under the influence of all independent factors, the Index of Economic Development of Enterprises Engaged in Innovation Activities, the Salary Index of Employees Involved in Innovation Activities, and the Index of the Use of Current Assets decreased in the crisis year 2008. At the same time, in the pre-crisis 2007, these indices showed an increase. A similar situation was observed in 2015. The crisis had a negative impact on the wages of employees of the innovation sector of the Russian economy, as well as on the number of employees working in the innovation sector of the economy of the Russian Federation.

Despite this, it can be said that the world crisis has provided the Russian economy with an opportunity to increase energy efficiency and competitiveness, to carry out its structural 
adjustment. Russia cannot fail to take into account that the world economy is switching to environmental principles, and therefore it is necessary to build an appropriate strategy for the transition to sustainable development.

\section{References}

1. V. Frolova, O. Dolina, T. Shpil'kina, E3S Web Conf., 21, 04018 (2017)

2. A. Kovalev, N. Rebrova, M. Zhidkova, E3S Web Conf., 41, 04026 (2018)

3. E. Dotsenko E., N. Ezdina, E3S Web Conf., 41, 04048 (2018)

4. O. Borisova, V. Frolova, M. Livson, V. Biryukov, E3S Web Conf., 41, 04028 (2018)

5. A.I. Gentova, O.A. Milyushenko, Foreign experience of macroeconomic planning (OBFUGRF, Omsk, 2018)

6. O.A. Verkhovets, Innovations and their role in the economic growth of Russia (Omsk State University Pu., Omsk, 2011)

7. Yu.P. Dus, K.I. Grasmik, O.A. Verkhovets, UrFU Bulleting, 2, 62-72 (2013)

8. P.V. Zaitseva, O.A. Verkhovets, The impact of the global economic crisis on the innovation activities of the regions of the Russian Federation (OBFUGRF, Omsk, 2018)

9. The Internet Portal of the First Independent Rating Agency, URL: https://www.fira.ru. 